\title{
ADVISORY COMMITTEE TO NATIONAL REVIEW PANEL ON SCHOOL DESEGREGATION RESEARCH 1977-1979
}

Richard D. Ashmore, Associate Professor of Psychology, Livingston College, Rutgers University. Co-author, The Structure of Intergroup Perception: Categories and Dimensions in Views of Ethnic Groups and Adjectives Used in Stereotype Research, 25 J. Personality \& Soc. Psych. 428 (1973); Studies in Forced Compliance: XIII and $X V$ in Search of a Dissonance-Producing Forced Compliance Paradigm, I REPResentative Research in Soc. Psych. 11 (1970). Ph.D. in Psychology, University of California at Los Angeles.

Joel S. Berke, Senior Research Scientist, Educational Policy Research Institute, Educational Testing Service. Formerly Deputy Assistant Secretary for Education Policy Development, Department of Health, Education, and Welfare; Director of Education Policy Research Institute, Educational Testing Service. Author, Answers to Inequity: An Analysis of the New School Finance (1974). Co-author, Federal Aid to Education: Who Benefits? Who GovERns? (1972); Alternatives for Future Federal Programs, in Government IN THE Classroom: Dollars and Power in Education (1978); Research in School Finance: $A$ Concern with Equity and Equality, in Review of RESEARCH IN EducaTION (L. Shuman ed. 1976). Ph.D. in Political Science, Syracuse University.

Elbert D. Brooks, Director of Schools, Metropolitan Davidson County Public Schools, Nashville, Tennesse. Ed.D., Stanford University.

José A. Cardenas, Executive Director, Intercultural Development Research Association. Formerly a school teacher and a school superintendent. Author, Bilingual Education, Segregation, and a Third Alternative, 19 INEquality in Educ. 19 (1975). Ed.D., University of Texas.

Norman J. Chachkin, Senior Staff Attorney, Lawyers' Committee for Civil Rights Under Law, Washington, D.C. Formerly Associate Director for Policy, Planning and Research, Office for Civil Rights, Department of Health, Education, and Welfare; Staff Attorney, NAACP Legal Defense and Educational Fund, Inc. Co-author, 2 Emerson, Haber \& Dorsen's Political and Civil Rights in The United States (3d ed. Supp. 1975); Metropolitan School Desegregation: Evolving Law', 10 Integrated Educ. 13 (1972). LL.B., New York University School of Law. 
Joseph M. Cronin, State Superintendent of Education, Illinois. Formerly State Secretary of Educational Affairs, Massachusetts; Associate Dean, Harvard Graduate School of Education. Author, The Conrrol of Urban Schools: Perspective on the Power of Educational Reformers (1973); The State and School Desegregation, 17 Theory into Practice 3 (1978); City School Desegregation and Creative Uses of Enrollment Decline, 86 Integrated Educ. 10 (1977). Co-author, Organizing an Urban School System for Diversity (1973). Ed. D., Stanford University.

Richard P. Duran, Postdoctoral Fellow, Educational Testing Service; Director, National Institute of Education research project, Logical Reasoning Skills of Puerto Rican Bilinguals. Editor, Discourse Research Update section of La Red, the newsletter of the National Chicano Research Network. Editor, Latino Language and Communicative Behavior (forthcoming). Author of numerous papers presented at various psychology conferences. Ph.D. in Psychology, University of California at Berkeley.

Ricardo R. Fernández, Associate Professor, Department of Cultural Foundations of Education, and Director, Midwest National Origin Desegregation Assistance Center, University of Wisconsin at Milwaukee. Member, Governor's Committee on Hispanic Affairs, Wisconsin; Wisconsin State Advisory Committee, U.S. Commission on Civil Rights. Advisor to Citywide Bilingual Bicultural Advisory Committee, Milwaukee. Co-author, Bilingual Education and Desegregation: A New Dimension in Legal and Educational Decision-Making, in BIlingual Education (B. Persky, L. Golubchick, \& H. La Fontaine eds. 1978); Toward the Development of Minimal Specifications for Lau-Related Language Assessments, in School Desegregation: A Model at Work (F. Aquila \& J. Stroehr eds. 1978). Ph.D. in Romance Languages and Literatures, Princeton University.

Robert Glaser, University Professor of Psychology and Education, and Codirector, Learning Research and Development Center, University of Pittsburgh. Member, National Academy of Education; Publications and Communications Board, American Psychological Association. Formerly President, American Educational Research Association; President, Educational Psychology Division, American Psychological Association. Editor of Advances in Instructional Psychology. Author, Adaptive Education: Individual Diversity AND LEARNING (1977); other books and numerous papers on instructional psychology. Ph.D. in Psychology, Indiana University.

Arthur Jefferson, General Superintendent of Schools, Detroit, Michigan. Ed.D., Wayne State University.

Hon. William Wayne Justice, Judge, United States District Court for the Eastern 
District of Texas since his appointment by President Lyndon B. Johnson in 1968. LL.B., University of Texas School of Law.

Hon. James B. McMillan, Judge, United States District Court for the Western District of North Carolina since his appointment by President Lyndon $B$. Johnson in 1968. J.D., Harvard University School of Law.

Hon. Robert R. Merhige, Jr., Judge, United States District Court for the Eastern District of Virginia since his appointment by President Lyndon B. Johnson in 1967. Adjunct Professor of Law, T.C. Williams School of Law, University of Richmond. LL.B., T.C. Williams School of Law.

Thomas K. Minter, Deputy Commissioner for Elementary and Secondary Education, U.S. Office of Education. Formerly Superintendent of Public Schools, Wilmington, Delaware; Superintendent of School District Seven, Philadelphia, Pennsylvania. Author, Intermediate School 201, Manhattan: Center of Controversy (1967). Ed.D., Harvard University.

Janet W. Schofield, Assistant Professor of Psychology, University of Pittsburgh. Principal investigator in three studies of desegregation, sponsored by the $\mathrm{Na}$ tional Institute of Education and the National Institute of Mental Health. Author, The Impact of Positively Structured Contact on Intergroup Attitudes, in Social Psychology of Education: Theory and Research (D. Bar-Tal \& L. Saxe eds. 1978). Co-author, Unplanned Social Learning in an Interracial School, in Desegregated Schools: Appraisals of an American Experiment (R. Rist ed. 1979). Ph.D. in Social Relations, Harvard University.

Margaret Beale Spencer, Assistant Professor of Psychology, Emory University. Member of editorial review board, Journal of Educational and Social Analysis. Formerly Research Project Director, University of Chicago; Research Consultant, Howard University. Author, The Competence Model as a Viable Alternative to IQ Test Gamesmanship, in Proceedings of The Association of Black Psychologists (1976). Co-author, Effects of Systematic Social and Token Reinforcement on the Modification of Racial and Color Concept Attitudes in Black and in White Preschool Children, 9 Developmental Psych. 246 (1973). Ph.D. in Psychology, University of Chicago.

Gail E. Thomas, Assistant Professor of Social Relations, and Research Scientist, Center for the Social Organization of Schools, Johns Hopkins University. Editor, Blacks in Higher Education in the 70s (forthcoming). Author, Equality of Representation of Race and Sex Groups in Higher Education: Institutional and Program Enrollment Statuses (Johns Hopkins University Center for the Social Organization of Schools Report No. 263, October 1978); The Influence of Ascription, Achievement and Educational Expectations on Black-White Post- 
Secondary Enrollment, 20 Soc. Q. (1979) (forthcoming). Co-author, Access to Higher Education: The Importance of Race, Sex, Social Class, and Academic Credentials, 87 School Rev. 133 (1979). Ph.D. in Sociology, University of North Carolina at Chapel Hill.

Meyer Weinberg, Director, Center for Equal Education, University of Massachusetts. Editor of Integrated Education; Research Review of Equal Education. Author, A Chance to Learn (1977); Minority Students: A Research APPraIsal (1977); Desegregation and Quality Education: Quality and Equality in Our Schools, in Three Myths: An Exposure of Popular Misconceptions About School Desegregation (1976); numerous other articles and books on school desegregation. M.A. in History and Social Science, University of Chicago.

Ben Williams, Director, National Project and Task Force on Desegregation Strategies, Denver, Colorado. Formerly Associate Dean and Chairman, Urban Education Division, National College of Education, Evanston, Illinois; Executive Director, Human Relations Commission, Evanston, Illinois. Author, School Desegregation: The State's Role, 12 Compact 14 (1978). Co-author, School Desegregation-The Non-Traditional Sociological Perspective, 47 J. NEGRo Educ. 72 (1978). Ph.D. in Educational Administration and Urban Affairs, Northwestern University.

John B. Williams, Assistant Professor of Education, Doctoral Studies Division, Fairleigh Dickinson University. Formerly consultant to the director, National Institute of Education. Author, The History and Goals of Black Colleges and Universities, in Black Colleges in America: Challenge, Development, Survival (C. Willie \& R. Edmonds eds. 1978); Blacks on Campus: Integration by Evasion, The Nation, November 17, 1969, at 537. Ph.D. in Education and Social Policy, Harvard University.

Paul M. Wortman, Professor of Psychology, University of Michigan; Institute of Social Research, University of Michigan. Formerly Director, Office of Evaluation Research, Northwestern University. Author, Programming, Planning and Evaluation: A System for Assessing Social Policy, in Policy Studies and the SoCial Sciences (S. Nagel ed.. 1975). Co-author, The Riverside School Study of Desegregation: A Re-Examination, Research Review of Equal Education (forthcoming); The First Year of the Education Voucher Demonstration: A Secondary Analysis of Student Achievement Test Scores, 2 Evaluation Q. 193 (1978); Toward the Proper Conduct of Social Program Evaluations, 4 Evaluation 189 (1977). Ph.D. in Psychology, Carnegie-Mellon University. 